\title{
PEMBUATAN VISUM ET REPERTUM OLEH DOKTER SEBAGAI UPAYA MENGUNGKAP PERKARA DI DALAM PROSES PERADILAN Oleh: HANGSI PRIYANTO ${ }^{1}$
}

\begin{abstract}
The making of Visum et Repertum gives full duty to doctors as implementers in the field to assist prosecutors in determining the direction of the charges that will be charged against the defendant, as well as assisting the judge in finding material truth in deciding criminal cases. This research is aimed at knowing and analyzing the technique of making Visum et Repertum by doctors as an effort to uncover cases in the judicial process. In addition, it is also intended to find out the authority to make Visum et Repertum by forensic experts and analyze the role of Visum et Repertum for judges in disclosing cases in the judicial process. The study uses a normative juridical approach, with secondary data sources.

The results showed that the technique of making Visum et Repertum by doctors as an effort to uncover cases in the judicial process was divided into techniques which were examination of wounded victims, techniques for examining sexual crime victims, child victim examination techniques, extermination examination techniques and autopsies and psychiatric examination techniques. Visum et Repertum (VeR) was made at the request of the National Police investigator through an official letter signed at least by the Sector Police Chief. Visum et Repertum does not have to be made by a forensic specialist. The subjects making visum et repertum in the judicial process are also distinguished on the division of abilities, namely by the specialization stipulated in the legislation and the subject of general visum et repertum makers. The role of Visum et Repertum for judges in disclosing cases in the judicial process is the completeness of evidence in pro-judicial cases with examinations in court proceedings, assisting in efforts to increase the judge's confidence in decision making.
\end{abstract}

Keywoeds: visum et repertum, court, doctors

\begin{abstract}
Abstrak
Pembuatan Visum et Repertum memberikan tugas sepenuhnya kepada dokter sebagai pelaksana di lapangan untuk membantu jaksa dalam menentukan arah dakwaan yang akan didakwakan terhadap terdakwa, serta membantu hakim dalam menemukan kebenaran materil dalam memutuskan perkara pidana. Penelitian ini ditujukan untuk mengetahui dan menganalisis teknik pembuatan Visum et Repertum oleh dokter sebagai upaya mengungkap perkara di dalam proses peradilan. Selain itu juga ditujukan untuk mengetahui kewenangan pembuatan Visum et Repertum oleh dokter ahli forensik dan menganalisis peranan Visum et Repertum bagi hakim dalam mengungkap perkara di dalam proses peradilan. Penelitian menggunakan metode pendekatan yuridis normatif, dengan sumber data sekunder.

Hasil penelitian menunjukan bahwa, teknik pembuatan Visum et Repertum oleh dokter sebagai upaya mengungkap perkara di dalam proses peradilan terbagi atas yaitu teknik pemeriksaan korban luka, teknik pemeriksaan korban kejahatan seksual teknik pemeriksaan korban anak, teknik pemeriksaan luar jenazah dan autopsi serta teknik pemeriksaan kejiwaan. Visum et Repertum $(\mathrm{VeR})$ dibuat atas permintaan dari penyidik Polri melalui surat resmi yang ditandatangani minimal oleh Kepala Kepolisian Sektor. Visum et Repertum tidak harus dibuat oleh dokter ahli forensik. Subjek pembuat visum et repertum di dalam proses peradilan juga dibedakan atas pembagian kemampuan yaitu dengan pengkhususan yang diatur dalam peraturan perundang-undangan dan subjek pembuat visum et repertum pada umumnya. Peranan Visum et Repertum bagi hakim
\end{abstract}

\footnotetext{
${ }^{1}$ Pengacara Komite Advokat Indonesia, Hangsi_priyanto@gmail.com
} 


\section{7 | Jurnal Idea Hukum \\ Vol. 5 No. 1 Maret 2019 \\ Magister Hukum Fakultas Hukum Universitas Jenderal Soedirman}

dalam mengungkap perkara di dalam proses peradilan adalah sebagai kelengkapan alat bukti dalam berkas perkara pro yustisial dengan pemeriksaan dalam sidang pengadilan, membantu dalam usaha untuk menambah keyakinan hakim dalam hal pengambilan keputusan.

Kata kunci: visum et repertum, peradilan dan para dokter

\section{A. Latar Belakang Masalah}

Visum et Repertum adalah suatu keterangan dokter tentang apa yang dilihat dan ditemukan di dalam melakukan pemeriksaan tentang orang yang luka atau terhadap mayat yang merupakan keterangan tertulis. ${ }^{2}$ Visum et Repertum adalah keterangan yang dibuat dokter atas permintaan penyidik yang berwenang mengenai hasil pemeriksaan medis terhadap manusia, hidup maupun mati, ataupun bagian/diduga bagian tubuh manusia, berdasarkan keilmuannya dan di bawah sumpah untuk kepentingan peradilan. Penegak hukum mengartikan Visum et Repertum sebagai laporan tertulis yang dibuat dokter berdasarkan sumpah atas permintaan yang berwajib untuk kepentingan peradilan tentang segala hal yang dilihat dan ditemukan menurut pengetahuan yang sebaik-baiknya.

Visum et Repertum turut berperan dalam proses pembuktian suatu perkara pidana terhadap kesehatan dan jiwa manusia. Visum et Repertum menguraikan segala sesuatu tentang hasil pemeriksaan medik yang tertuang di dalam Pemberitaan, yang karenanya dapat dianggap sebagai benda

2 R. Atang Ranoemihardja, 2003, Ilmu Kedokteran Kehakiman, Tarsito, Bandung, hal. 18 bukti. Visum et Repertum juga memuat keterangan atau pendapat dokter mengenai hasil pemeriksaan medik tersebut yang tertuang di bagian Kesimpulan. Dengan demikian Visum et Repertum secara utuh telah menjembatani ilmu kedokteran dengan ilmu hukum sehingga dengan membaca Visum et Repertum dapat diketahui dengan jelas apa yang telah terjadi pada seseorang dan para praktisi hukum dapat menerapkan norma-norma hukum pada perkara pidana yang menyangkut tubuh/jiwa manusia.

Pemeriksaan suatu perkara pidana di dalam suatu proses peradilan pada hakekatnya adalah bertujuan untuk mencari kebenaran materiil terhadap perkara tersebut. Hal ini dapat dilihat dari adanya berbagai usaha yang dilakukan oleh aparat penegak hukum dalam memperoleh bukti-bukti yang dibutuhkan untuk mengungkap suatu perkara baik pada tahap pemeriksaan pendahuluan seperti penyidikan dan penuntutan maupun pada tahap persidangan perkara tersebut.

\section{B. Rumusan Masalah}

Berdasarkan latar belakang tersebut di atas maka dapat dirumuskan perumusan masalah sebagai berikut : 
1. Bagaimanakah teknik pembuatan Visum et Repertum oleh dokter sebagai upaya mengungkap perkara di dalam proses peradilan?

2. Apakah Visum et Repertum harus dibuat oleh dokter ahli forensik?

3. Bagaimanakah peranan Visum et Repertum bagi hakim dalam mengungkap perkara di dalam proses peradilan ?

\section{E. Metode Penelitian}

1. Metode : Yuridis Normatif Pendekatan

2. Spesifikasi : Preskriptif Penelitian

3. Jenis data : Data primer dan data sekunder

4. Metode : Studi kepustakaan Pengambilan atau studi Data dokumen.

5. Teknik : Teks naratif. Penyajian Data

6. Analisa Data : Kualitatif.

F. Hasil dan Pembahasan

1.Teknik Pembuatan Visum et Repertum Oleh Dokter Sebagai Upaya

Mengungkap Perkara di Dalam Proses Peradilan

KUHAP tidak mengatur prosedur rinci apakah korban harus diantar oleh petugas kepolisian atau tidak. Padahal petugas pengantar tersebut sebenarnya dimaksudkan untuk memastikan kesesuaian antara identitas orang yang akan diperiksa dengan identitas korban yang dimintakan Visum et Repertumnya seperti yang tertulis di dalam surat permintaan Visum et Repertum. Situasi tersebut membawa dokter turut bertanggung jawab atas pemastian kesesuaian antara identitas yang tertera di dalam surat permintaan Visum et Repertum dengan identitas korban yang diperiksa.

Tahapan-tahapan dalam pembuatan Visum et Repertum antara lain dapat dijabarkan sebagai berikut:

a. Penerimaan korban yang dikirim oleh Penyidik.

Yang berperan dalam kegiatan ini adalah dokter, mulai dokter umum sampai dokter spesialis yang pengaturannya mengacu pada Standar Prosedur Operasional (SPO). Yang diutamakan pada kegiatan ini adalah penanganan kesehatannya dulu, bila kondisi telah memungkinkan barulah ditangani aspek medikolegalnya. Tidak tertutup kemungkinan bahwa terhadap korban dalam penanganan 


\section{9 | Jurnal Idea Hukum \\ Vol. 5 No. 1 Maret 2019 \\ Magister Hukum Fakultas Hukum Universitas Jenderal Soedirman}

medis melibatkan berbagai

disiplin spesialis.

b. Penerimaan surat permintaan keterangan ahli/visum et revertum

Adanya surat permintaan keterangan ahli/Visum et Repertum merupakan hal yang penting untuk dibuatnya Visum et Repertum tersebut. Dokter sebagai penanggung jawab pemeriksaan medikolegal harus meneliti adanya surat permintaan tersebut sesuai ketentuan yang berlaku. Hal ini merupakan aspek yuridis yang sering menimbulkan masalah, yaitu pada saat korban akan diperiksa surat permintaan dari penyidik belum ada atau korban (hidup) datang sendiri dengan membawa surat permintaan Visum et Repertum.

c. Pemeriksaan korban secara medis

Tahap ini dikerjakan oleh dokter dengan menggunakan ilmu forensik yang telah dipelajarinya. Namun tidak tertutup kemungkinan dihadapi kesulitan yang mengakibatkan beberapa data terlewat dari pemeriksaan.

Ada kemungkinan didapati benda bukti dari tubuh korban misalnya anak peluru, dan sebagainya. Benda bukti berupa pakaian atau lainnya hanya diserahkan pada pihak penyidik. Dalam hal pihak penyidik belum mengambilnya maka pihak petugas sarana kesehatan harus menyimpannya sebaik mungkin agar tidak banyak terjadi perubahan. Status benda bukti itu adalah milik negara, dan secara yuridis tidak boleh diserahkan pada pihak keluarga/ahli warisnya tanpa melalui penyidik.

d. Pengetikan surat keterangan ahli/Visum et Repertum

Pengetikan berkas keterangan ahli/Visum et Repertum oleh petugas administrasi memerlukan perhatian dalam bentuk/formatnya karena ditujukan untuk kepentingan peradilan. Misalnya penutupan setiap akhir alinea dengan garis, untuk mencegah penambahan kata-kata tertentu oleh pihak yang tidak bertanggung jawab. Contoh : "Pada pipi kanan ditemukan luka terbuka, tapi tidak rata sepanjang lima senti meter ----$---“$

e. Penandatanganan surat keterangan ahli/Visum et Repertum 
Undang-undang menentukan bahwa yang berhak menandatanganinya adalah dokter. Setiap lembar berkas keterangan ahli harus diberi paraf oleh dokter. Sering terjadi bahwa surat permintaan visum dari pihak penyidik datang terlambat, sedangkan dokter yang menangani telah tidak bertugas di sarana kesehatan itu lagi. Dalam hal ini sering timbul keraguan tentang siapa yang harus menandatangani visum et repertun korban hidup tersebut. Hal yang sama juga terjadi bila korban ditangani beberapa dokter sekaligus sesuai dengan kondisi penyakitnya yang kompleks.

f. Penyerahan benda bukti yang telah selesai diperiksa

Benda bukti yang telah selesai diperiksa hanya boleh diserahkan pada penyidik saja dengan menggunakan berita acara.

g. Penyerahan surat keterangan ahli/Visum et Repertum.

Surat keterangan ahli/Visum et Repertum juga hanya boleh diserahkan pada pihak penyidik yang memintanya saja. Dapat terjadi dua instansi penyidikan sekaligus meminta surat Visum et Repertum. Penasehat hukum tersangka tidak diberi kewenangan untuk meminta Visum et Repertum kepada dokter, demikian pula tidak boleh meminta salinan Visum et Repertum langsung dari dokter. Penasehat hukum tersangka dapat meminta salinan Visum et Repertum dari penyidik atau dari pengadilan pada masa menjelang persidangan.

Pembuatan Visum et Repertum memiliki teknik yang berbeda beda tergantung objek yang akan diperiksa. Teknik Pemeriksaan Korban/ pembuatan Visum et Repertum dapat dibedakan menjadi sebagai berikut:

$$
\begin{aligned}
& \text { 1. Teknik Pemeriksaan } \\
& \text { Korban Luka } \\
& \text { Teknik pemeriksaan pada } \\
& \text { kasus korban hidup baik luka, } \\
& \text { maupun kejahatan } \\
& \text { seksual/perkosaan, pada } \\
& \text { prinsipnya sama dengan } \\
& \text { pemeriksaan prosedur klinis } \\
& \text { lainnya. Pemeriksaan tersebut } \\
& \text { secara umum mencakup } \\
& \text { anamnesis, pemeriksaan fisik dan } \\
& \text { pemeriksaan penunjang bila } \\
& \text { diperlukan. Terdapat perbedaan } \\
& \text { yang mendasar antara } \\
& \text { pemeriksaan medikolegal dengan } \\
& \text { pemeriksaan klinis untuk } \\
& \text { kepentingan pengobatan, yaitu } \\
& \text { pemeriksaan medikolegal } \\
& \text { bertujuan untuk menegakkan } \\
& \text { hukum pada suatu peristiwa }
\end{aligned}
$$




\section{1 | Jurnal Idea Hukum}

Vol. 5 No. 1 Maret 2019

Magister Hukum Fakultas Hukum Universitas Jenderal Soedirman

pidana yang dialami korban melalui penyusunan Visum et Repertum yang baik. Oleh karena itu penting diperhatikan ada tidaknya tanda-tanda kekerasan yang merupakan hasil suatu tindak pidana.

2. Teknik Pemeriksaan

Korban Kejahatan Seksual

Salah satu kejahatan yang terdapat dalam Kitab UndangUndang Hukum Pidana ialah Tindak pidana perkosaan diatur dalam Pasal 285 KUHP, Bab XIV tentang Kejahatan Terhadap Kesusilaan. Namun demikian ada Pasal-Pasal lain yang dapat digunakan untuk menjaring pelaku perkosaan, yaitu Pasal 286 dan 287 KUHP. Pasal 285 KUHP sifatnya adalah Pasal pokok untuk kasus perkosaan. Ketiga Pasal tersebut mengandung unsur yang sama yaitu adanya persetubuhan diluar perkawinan.

Adapun unsur-unsur selengkapnya tentang perkosaan menurut R.Sugandhi adalah :

a. Pemaksaan bersetubuh oleh lakilaki kepada wanita yang bukan menjadi istrinya.

b. Pemaksaan bersetubuh itu diikuti dengan tindakan atau ancaman kekerasan.

c. Kemaluan pria harus masuk pada lubang kemaluan wanita, dan

d. Mengeluarkan air mani. $^{3}$

Pendapat itu menunjukkan pada suatu perkosaan yang terjadi secara tuntas, artinya pihak pelaku (laki-laki pemerkosa) telah menyelesaikan perbuatannya hingga selesai (mengeluarkan air mani). Jika hal ini tidak sampai terjadi, maka secara eksplisit, apa yang dilakukan laki-laki itu belum patut dikategorikan sebagai perkosaan.

Dua aspek yang penting diperhatikan pada kasus kejahatan seksual / perkosaan adalah :

a. mengumpulkan bukti-bukti persetubuhan, seperti robekan selaput dara, adanya cairan mani dan atau sel sperma.

b. mencari tanda-tanda kekerasan, seperti riwayat kehilangan kesadaran dan luka-luka.

3. Teknik Pemeriksaan

Korban Kekerasan

terhadap Anak

Kekerasan terhadap anak merupakan tindak pidana yang melanggar hak asasi manusia yang bila dibiarkan akan memberikan dampak negatif

${ }^{3} I b i d .$, hal. 41 
terhadap kesehatan dan tumbuhkembang anak serta mengancam kualitas hidup dan masa depannya, sehingga memerlukan penanganan. Penanganan anak korban kekerasan perlu dilakukan secara kompherensif dengan pendekatan multidispliner baik hukum, medis, maupun psikologis.

Pada kasus di mana korbannya adalah anak-anak, sesuai dengan Peraturan Menteri Kesehatan Nomor 63 Tahun 2013 tentang Kewajiban Pemberi Layanan Kesehatan Untuk Memberikan Informasi Atas Adanya Dugaan Kekerasan Terhadap Anak, maka pemberi layanan kesehatan meliputi fasilitas pelayanan kesehatan dan tenaga kesehatan mempunyai kewajiban:

a. memberikan pertolongan pertama;

b. memberikan konseling awal;

c. menjelaskan kepada orang tua anak tentang keadaan anak dan dugaan penyebabnya, serta mendiskusikan langkah-langkah ke depan;

d. melakukan rujukan apabila diperlukan; e. memastikan keselamatan anak;

f. melakukan pencatatan lengkap di dalam rekam medis serta siap untuk membuat Visum et Repertum apabila diminta secara resmi; dan

g. memberikan informasi kepada kepolisian.

Peraturan Menteri Kesehatan Nomor 63 Tahun 2013 tentang Kewajiban Pemberi Layanan Kesehatan Untuk Memberikan Informasi Atas Adanya Dugaan Kekerasan Terhadap Anak mewajibkan pemberi layanan memberikan informasi kepada pihak yang berwenang. Pasal 7 Peraturan Menteri Kesehatan Nomor 63 Tahun 2013 tentang Kewajiban Pemberi Layanan Kesehatan Untuk Memberikan Informasi Atas Adanya Dugaan Kekerasan Terhadap Anak menyatakan bahwa, pemberi layanan kesehatan yang dalam melakukan pelayanan kesehatan menemukan adanya dugaan kekerasan terhadap anak wajib memberitahukan kepada orang tua dan/atau pendamping anak tersebut. Pemberitahuan tersebut 


\section{3 | Jurnal Idea Hukum}

Vol. 5 No. 1 Maret 2019

Magister Hukum Fakultas Hukum Universitas Jenderal Soedirman

disertai anjuran untuk melaporkan dugaan kekerasan terhadap anak tersebut kepada kepolisian. Anjuran paling sedikit berisi:

a. dampak yang merugikan

kesehatan anak;

b. dampak sosial terhadap anak; dan

c. tindakan sanksi hukum yang memberi efek jera bagi pelaku.

d. Teknik Pemeriksaan Luar Jenazah dan autopsi

Demi untuk kepentingan pengadilan, penyidik meminta keterangan ahli. Permuntaan tersebut dilakukan oleh penyidik harus secara tertulis dengan menyebut secara tegas untuk hal apa pemeriksaan ahli itu dilakukan, misalnya apakah untuk pemeriksaan luka (pemeriksaan luar) atau pemeriksaan mayat (pemeriksaan dalam) dengan pemeriksaan bedah mayat (autopsy). ${ }^{4}$ Atas permintaan penyidik, ahli yang bersangkutan membuat laporan yang bentuknya dapat berupa keterangan yang lazim disebut Visum et Repertum. Laporan atau Visum et Repertum

4 Abdul Mun'im Idries, 2003, Pedoman Praktis Ilmu Kedokteran Forensik bagi Praktisi Hukum, Sagung Seto, Jakarta, hal. 9 dibuat oleh ahli yang bersangkutan, mengingat sumpah diwaktu ahli menerima jabatan/pekerjaan.

Mayat apabila dibiarkan bukan hanya membusuk, akan tetapi sudah merupakan keharusan bahwa mayat harus selekasnya dikubur. Seseorang yang mati karena menjadi korban kejahatan atau setidak-tidaknya patut diduga sebagai akibat kejahatan, maka keberadaan mayat yang menjadi barang bukti yang akan dijakikan dasar diperolehnya alat bukti. Peristiwa pidana yang menyebabkan matinya orang sementara alat bukti yang lain yaitu seseorang yang melihat sendiri, mendengar sendiri atau dialami sendiri maka saksi diam (physical evidence) diharapkan mampu mengungkapkan semua misteri yang ada di dalamnya. ${ }^{5}$

\section{Teknik Pemeriksaan \\ Kejiwaan \\ Van Hamel menyebutkan,} bahwa hukum pidana adalah keseluruhan dasar dan aturan yang dianut oleh negara dalam kewajibannya untuk menegakkan hukum, yakni dengan melarang apa yang bertentangan dengan

\footnotetext{
${ }^{5}$ Koesparmono Irsan, 2016, Panduan Memahami Hukum Pembuktian dalam Hukum Perdata dan Hukum Pidana, Gramata Publishing, Bekasi, hal. 245
} 
hukum (onrecht) dan

Pasal 44 ayat (1) Kitab

mengenakan suatu nestapa

(penderitaan) kepada yang

melanggar larangan tersebut.

Bertitik tolak pada definisi ini, dapat ditarik tiga masalah pokok dalam hukum pidana, yakni (1) masalah perbuatan yang dilarang dan diancam dengan pidana, atau yang lazim disebut tindak pidana; (2) masalah pertanggungjawaban pidana dari orang yang melakukan perbuatan yang dilarang dan diancam pidana itu, atau disebut kesalahan; dan (3) masalah sanksi atau pidana. ${ }^{6}$

Kemampuan bertanggung jawab (toerekeningsvatbaarheid) ini adalah perihal seseorang yang dapat dibebani tanggung jawab atas sikap tindakannya, syaratsyarat kemampuan bertanggung jawab sendiri menurut Van Hamel, yakni: Keadaan psikologisnya adalah sehat, sehingga dapat mengerti akan: (a) Niat perbuatan, (b) Akibat perbuatan; (2) Haruslah dalam keadaan bebas untuk menentukan kehendaknya; (3) Sadar bahwa perbuatannya adalah larangan (jadi subjektif). ${ }^{7}$

${ }^{6}$ Sudaryono dan Natangsa Surbakti, 2005, Buku Penganggan Kuliah: Hukum Pidana, Fakultas Hukum Universitas Muhammadiyah Surakarta, Surakarta, hal. 2.

${ }^{7}$ Zamhari Abidin, 1986, Pengertian dan Asas Hukum Pidana dalam Schema Undang-Undang Hukum Pidana (KUHP) menetapkan bahwa "Barang siapa melakukan perbuatan yang tidak dapat dipertanggungkan kepadanya karena jiwanya cacat dalam pertumbuhan atau terganggu karena penyakit tidak dipidana". Berkaitan dengan pasal dimaksud perlu disadari bahwa bukanlah tugas Dokter spesialis kedokteran jiwa yang membuat VeRP untuk menentukan pertanggungjawaban

terperiksa karena pengertian itu bukanlah pengertian dalam disiplin ilmu kedokteran. Penentuan pertanggungjawaban tersebut adalah hak dari hakim pengadilan. Dokter spesialis kedokteran jiwa dapat membantu hakim dengan mengemukakan unsur-unsur yang dapat menentukan pertanggunganjawaban terperiksa.

Pemeriksaan Kesehatan Jiwa untuk kepentingan penegakan hukum perkara pidana bertujuan menilai unsur-unsur:

(Bagan) dan Synopsis (Catatan Singkat), Ghalia Indonesia, Jakarta, hal. $44-45$. 


\section{5 | Jurnal Idea Hukum}

Vol. 5 No. 1 Maret 2019

Magister Hukum Fakultas Hukum Universitas Jenderal Soedirman

a. Kemampuan

Terperiksa

dalam

mempertanggungja

wabkan tindak

pidana yang telah

dilakukannya;

b. dampak psikologis pada Terperiksa

yang menjadi korban tindak

pidana; dan/atau

c. kecakapan mental

Terperiksa untuk menjalani proses peradilan pidana.

Pasal 4 Peraturan Menteri

Kesehatan Republik Indonesia Nomor 77 Tahun 2015 Tentang Pedoman Pemeriksaan

Kesehatan Jiwa Untuk

Kepentingan Penegakan Hukum, menyatakan bahwa pemeriksaan Kesehatan Jiwa untuk kepentingan penegakan hukum perkara pidana harus diselenggarakan di rumah sakit milik pemerintah dan pemerintah daerah.

Sarana pelayanan kesehatan jiwa tempat membuat VeRP adalah Rumah Sakit Jiwa Pemerintah, Bagian Kedokteran Jiwa pada Rumah Sakit Umum Pemerintah,Tentara Nasional Indonesia dan Kepolisian
Republik Indonesia. Untuk pemeriksaan VeRP Perdata dapat juga dilaksanakan di Klinik Utama yang memiliki sumber daya yang sesuai.

Sarana dan prasarana yang diperlukan diprioritaskan bagi keamanan dan pengawasan terperiksa untuk:

a. Mencegah larinya terperiksa, perlu ada penjagaan yang dilakukan oleh instansi pemohon. Larinya terperiksa menjadi tanggung jawab pemohon.

b. Menghindari terjadinya percobaan bunuh diri atau pembunuhan, kekerasan pada diri sendiri dan orang lain.

2. Subjek Pembuat Visum et Repertum di Dalam Proses Peradilan

Prosedur permintaan Visum et Repertum korban mati telah diatur dalam Pasal 133 dan 134 KUHAP yaitu dimintakan secara tertulis, mayatnya harus diperlakukan dengan baik, disebutkan dengan jelas pemeriksaan yang diminta, dan mayat diberi label yang memuat identitas yang diberi cap 
jabatan dan dilekatkan ke bagian tubuh mayat tersebut. Pemeriksaan terhadap mayat harus dilakukan selengkap mungkin dan hasil pemeriksaan tersebut dituangkan dalam bentuk Visum et Repertum yang harus dapat dianggap sebagai salinan dari mayat tersebut.

Pemeriksaan kedokteran forensik terhadap mayat sebenarnya bersifat obligatory atau keharusan dan tidak boleh dicegah. Pemberian informasi yang jelas tentang maksud, tujuan dan cara pemeriksaan mayat serta manfaatnya kepada keluarga korban diharapkan akan dapat menghindari kesalahpahaman antara pihak penyidik dengan pihak keluarga korban. Namun apabila jalan damai ini tidak dapat ditempuh, maka pemeriksaan mayat tetap dapat dilaksanakan secara paksa dan dapat dengan menerapkan Pasal 222 KUHP.

Sebagaimana telah dijelaskan dalam pembahasan pertama, yaitu terdapat beberapa teknik pembuatan Visum et Repertum yaitu teknik pemeriksaan korban luka, teknik pemeriksaan korban kejahatan seksual teknik pemeriksaan korban anak, teknik pemeriksaan luar jenazah dan autopsi serta teknik pemeriksaan kejiwaan. Berdasarkan teknik-teknis tersebut, maka sudah sewajarnya dokter memiliki kemampuan khusus. Subjek pembuat Visum et Repertum di dalam proses peradilan juga dibedakan atas pembagian kemampuan sebagai berikut:

1. Pengkhususan yang diatur dalam peraturan perundang-undangan

Khusus dalam pembuatan Visum et Repertum Psikiatrikum sesuai dengan Pasal 4 ayat (1) Peraturan Menteri Kesehatan Republik Indonesia Nomor 77 Tahun 2015 Tentang Pedoman Pemeriksaan Kesehatan Jiwa Untuk Kepentingan Penegakan Hukum, menyatakan bahwa Pemeriksaan Kesehatan Jiwa untuk kepentingan penegakan hukum perkara pidana harus diselenggarakan di rumah sakit milik pemerintah dan pemerintah daerah. Berdasarkan hal tersebut maka bukan saja dokternya harus khusus namun juga terdapat pembatasan fasilitas pelayanan kesehatan/ rumah sakit. Hanya rumah sakit milik pemerintah dan pemerintah daerah yang dapat mengeluarkan Visum et Repertum Psikiatrikum.

2. Subjek pembuat Visum et Repertum pada umumnya.

Visum et Repertum (VeR) merupakan salah satu bantuan yang sering diminta oleh pihak penyidik (polisi) kepada dokter 
1327 | Jurnal Idea Hukum

Vol. 5 No. 1 Maret 2019

Magister Hukum Fakultas Hukum Universitas Jenderal Soedirman

menyangkut perlukaan pada tubuh manusia. Visum et Repertum (VeR) merupakan alat bukti dalam proses peradilan yang tidak hanya memenuhi standar penulisan rekam medis, tetapi juga harus memenuhi hal-hal yang disyaratkan dalam sistem peradilan. ${ }^{8}$

Dalam praktik sehari-hari seorang dokter tidak hanya melakukan pemeriksaan medis untuk kepentingan diagnostik dan pengobatan penyakit saja, tetapi juga untuk dibuatkan suatu surat keterangan medis. Demikian pula halnya dengan seorang pasien yang datang ke instalasi gawat darurat, tujuan utama yang bersangkutan umumnya adalah untuk mendapatkan pertolongan medis agar penyakitnya sembuh. Namun dalam hal pasien tersebut mengalami cedera, pihak yang berwajib dapat meminta surat keterangan medis atau VeR dari dokter yang memeriksa. Jadi pada satu saat yang sama dokter dapat bertindak sebagai seorang klinisi yang bertugas mengobati penyakit sekaligus sebagai seorang petugas forensik yang bertugas membuat VeR.

8 Herkutanto. 2005, Peningkatan kualitas pembuatan visum et repertum (VeR) kecederaan di rumah sakit melalui pelatihan dokter unit gawat darurat (UGD). JPMK. 2005;8(3), hal. 163-9.
Menurut Budiyanto et al, dasar hukum VeR adalah sebagai berikut: ${ }^{9}$

Pasal 133 KUHAP
menyebutkan:
Dalam hal penyidik untuk
kepentingan peradilan
menangani seorang
korban baik luka,
keracunan ataupun mati
yang diduga karena
peristiwa yang merupakan
tindak pidana, ia
berwenang mengajukan
permintaan keterangan ahli
kepada ahli kedokteran
kehakiman atau dokter dan
atau ahli lainnya.
Permintaan keterangan ahli
sebagaimana dimaksud
dalam ayat (1) dilakukan
secara tertulis, yang dalam
surat itu disebutkan dengan
tegas untuk pemeriksaan
luka atau pemeriksaan
mayat dan atau
pemeriksaan bedah mayat.

KUHAP tidak membatasi orang yang berwenang dalam membuat Visum et Repertum Pasal 133 KUHAP hanya menyebutkan penyidik dapat mengajukan permintaan keterangan ahli kepada ahli kedokteran kehakiman atau dokter dan atau ahli lainnya. Pasal 133 KUHAP memberikan pilihan yang tidak limitatif yaitu penyidik dapat mengajukan permintaan keterangan ahli

9 Budiyanto A, Widiatmaka W, Sudiono S. 1997, Ilmu Kedokteran Forensik. Bagian Kedokteran Forensik Fakultas Kedokteran Universitas Indonesia, Jakarta, hal. 19. 
kepada ahli kedokteran kehakiman atau dokter dan atau ahli lainnya.

Pasal 133 sampai dengan pasal 135 KUHAP, pada tingkat pemeriksaan oleh penyidik dalam penyidikan, maka kata-kata "dok ter", peranan dokter (dokter bukan ahli kedokteran kehakiman) masih penting dan perlu serta dibutuhkan dalam tugas operasional di lapangan, terutama di daerah-daerah yang belum ada dokter ahli kedokteran kehakiman (para ahli lainnya).

\section{Peranan Visum et Repertum Bagi Hakim Dalam Mengungkap Perkara di Dalam Proses Peradilan}

Peranan keterangan ahli untuk kelengkapan alat bukti dalam berkas perkara pro yustisial dengan pemeriksaan dalam sidang pengadilan, amat membantu dalam usaha untuk menambah keyakinan hakim dalam hal pengambilan keputusan. peranan keterangan ahli di perlukan dalam setiap tahap proses pemeriksaan, hal itu tergantung pada perlu tidaknya mereka dilibatkan guna membantu tugas-tugas baik dari penyidik, jaksa, maupun hakim terhadap suatu perkara pidana seperti yang banyak terjadi dalam perkara tindak pidana pembunuhan, penganiayaan, tindak pidana keasusilaan dan tindak pidana kealpaan dan lain-lain. ${ }^{10}$

Visum et Repertum sebagai salah satu aspek peranan ahli dan atau adalah satu aspek keterangan ahli; maka keterkaitan antara keduanya tidak dapat dipisahkan. Keterangan ahli yang tertuang dalam suatu laporan hasil pemeriksaan adalah perwujudan hasil-hasil yang di buat berdasarkan atas ilmu dan teknik serta pengetahuan dan pengalaman yang sebaik-baiknya dari ahli itu. Misalnya peranan dokter ahli kedokteran kehakiman atau ahli psikiatri kehakiman di dalam menangani suatu kasus kejahatan yang telah terjadi, kemudian dipersoalkan, apakah suatu kejahatan terhadap nyawa orang itu merupakan pembunuhan ataukah penganiayaan yang mengakibatkan matinya orang itu ataupun dapat dicari sebab-sebab yang mendorong si pelaku melakukan perbuatan tersebut dilihat dari berbagai segi serta latar belakang kejiwaannya (kepribadian) dari si pelaku itu. Peranan hasil pemeriksaan berupa Visum et Repertum yang

${ }^{10}$ R. Soeparmono, 2002, Keterangan Ahli dan Visum et Repetum Dalam Aspek Hukum Acara Pidana, Mandar Maju Bandung, hal. 2. 
1329 | Jurnal Idea Hukum

Vol. 5 No. 1 Maret 2019

Magister Hukum Fakultas Hukum Universitas Jenderal Soedirman

dibuat oleh dokter ahli kedokteran

hakim mengambil langkah-

kehakiman atau psikiatri

langkah lain.

kehakiman dalam banyak perkara

kejahatan sangat banyak

membantu dalam proses

persidangan pengadilan, terutama

apabila dalam perkara tersebut

hanya di jumpai alat-alat bukti

yang amat minim (bewijs

minimum)

R. Atang Ranoemihardja ${ }^{11}$ menjelaskan kekuatan Visum et Repertum dalam pembuktian sebagaimana dimaksud dalam Staatsblad 1937 nomor 350 bahwa Visum et Repertum mempunyai daya bukti, sebab yang dimuat dalam pembuktiannya merupakan kesaksian, karena ia memuat segala sesuatu hal yang dilihat dan diketemukan pada waktu dilakukan pemeriksaan, jadi sama halnya dengan seseorang yang melihat dan merasakan sendiri, misalnya suatu kecelakaan di tempat peristiwa itu terjadi. Sedangkan kesimpulan Visum et Repertum dibuat untuk memudahkan bagi jaksa dan hakim, dengan catatan bahwa apabila kesimpulan itu logis maka dapat diterima, sebaliknya bila dianggap tidak logis, jaksa atau

11 R. Atang Ranoemihardja, 1991, Ilmu Kedokteran Kehakiman (Forensic Science), Tarsito, Bandung, hal. 25 
menggunakan kertas berkepala surat, bernomor dan bertanggal, diakhiri dengan tandatangan, nama jelas dan NIP/NRP pembuatnya, serta stempel dinas. Visum et Repertum harus diserahkan hanya kepada institusi penyidik pemintanya.

b. Visum et Repertum tidak harus dibuat oleh dokter ahli forensik. Subjek pembuat visum et repertum di dalam proses peradilan juga dibedakan atas pembagian kemampuan yaitu dengan pengkhususan yang diatur dalam peraturan perundang-undangan dan subjek pembuat visum et repertum pada umumnya. Pasal 6 Peraturan Menteri Kesehatan Republik Indonesia Nomor 77 Tahun 2015 Tentang Pedoman Pemeriksaan Kesehatan Jiwa Untuk Kepentingan Penegakan Hukum, yang menyatakan bahwa Pemeriksaan kesehatan jiwa untuk kepentingan penegakan hukum dilakukan oleh tim pemeriksa yang diketuai oleh dokter spesialis kedokteran jiwa. Tim pemeriksaan paling sedikit berjumlah 3 (tiga) orang terdiri atas satu orang dokter spesialis kedokteran jiwa dan tenaga kesehatan lain, atau beberapa orang dokter spesialis kedokteran jiwa.
Selain itu KUHAP tidak membatasi orang yang berwenang dalam membuat Visum et Repertum Pasal 133 KUHAP hanya menyebutkan penyidik dapat mengajukan permintaan keterangan ahli kepada ahli kedokteran kehakiman atau dokter dan atau ahli lainnya.

c. Peranan Visum et Repertum bagi hakim dalam mengungkap perkara di dalam proses peradilan adalah sebagai kelengkapan alat bukti dalam berkas perkara pro yustisial dengan pemeriksaan dalam sidang pengadilan, membantu dalam usaha untuk menambah keyakinan hakim dalam hal pengambilan keputusan.

\section{Saran}

a. Sebaiknya dibentuk peraturan menteri kesehatan yang khusus mengatur seorang dokter yang berwenang membuat Visum et Repertum (VeR), sesuai dengan spesialisasi dan kekhususan keahliannya.

b. Setiap dokter yang akan membuat Visum et Repertum (VeR) harus memperhatikan ketentuan dan memahami prosedur medikolegal dan terlatih secara teknis melakukan pemeriksaan yang diperlukan 


\title{
1331 | Jurnal Idea Hukum
}

Vol. 5 No. 1 Maret 2019

Magister Hukum Fakultas Hukum Universitas Jenderal Soedirman

\author{
serta mampu \\ menginterpretasikannya dengan \\ tepat.
}

\section{DAFTAR PUSTAKA}

Abidin, Zamhari. 1986. Pengertian dan Asas Hukum Pidana dalam Schema (Bagan) dan Synopsis (Catatan Singkat). Ghalia Indonesia. Jakarta.

Budiyanto A. Widiatmaka dan W. Sudiono S. 1997. IImu Kedokteran Forensik. Bagian Kedokteran Forensik Fakultas Kedokteran Universitas Indonesia. Jakarta.

Herkutanto. 2005. Peningkatan kualitas pembuatan visum et repertum (VeR) kecederaan di rumah sakit melalui pelatihan dokter unit gawat darurat (UGD). JPMK.

Idries, Abdul Mun'im. 2003. Pedoman Praktis IImu Kedokteran Forensik bagi Praktisi Hukum. Sagung Seto. Jakarta.

Irsan, Koesparmono. 2016. Panduan Memahami Hukum Pembuktian dalam Hukum Perdata dan Hukum Pidana. Gramata Publishing. Bekasi.

Ranoemihardja, R. Atang. 1991. IImu Kedokteran Kehakiman (Forensic Science). Tarsito. Bandung.

-----.. 2003. IImu Kedokteran Kehakiman. Tarsito. Bandung.

Soeparmono, R. 2002. Keterangan Ahli dan Visum et Repetum Dalam Aspek Hukum Acara Pidana. Mandar Maju Bandung.

Sudaryono dan Natangsa Surbakti. 2005. Buku Penganggan Kuliah: Hukum Pidana. Fakultas Hukum Universitas Muhammadiyah Surakarta. Surakarta. 